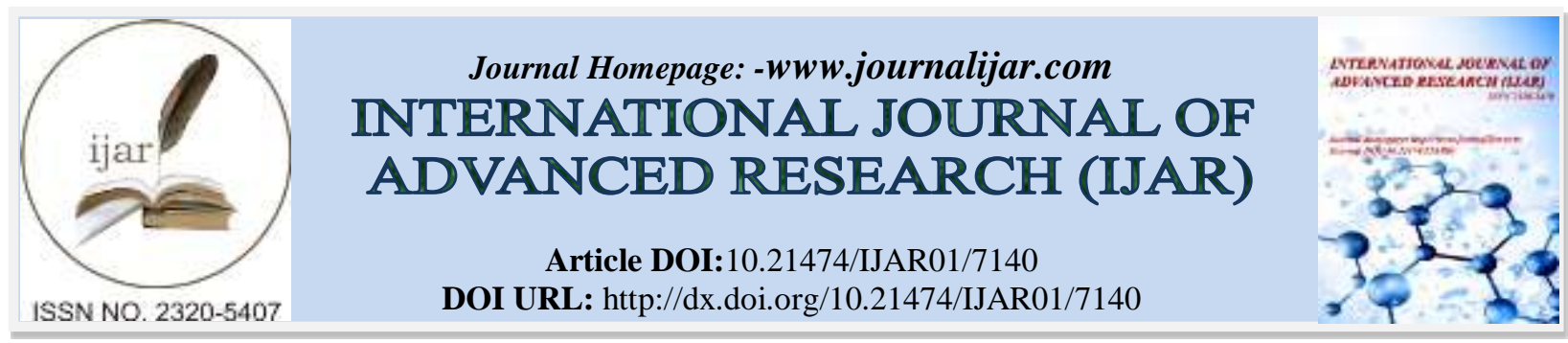

RESEARCH ARTICLE

\title{
ULTRASONIC DYEING OF COTTON FABRIC WITH AQUEOUS EXTRACT OF TERMINALIA ARJUNA.
}

\author{
S. Saivaraj ${ }^{1}$, G. Chandramohan ${ }^{2}$ and P. Saravanan ${ }^{3}$. \\ 1. Department of Chemistry, Thirumalai Engineering College, Kanchipuram, Tamil Nadu, India. \\ 2. Department of Chemistry, A.V.V.M Sri Pushpam College, Thanjavur, Tamil Nadu, India. \\ 3. Kings College of Engineering, Punalkulam, Thanjavur, Tamil Nadu, India.
}

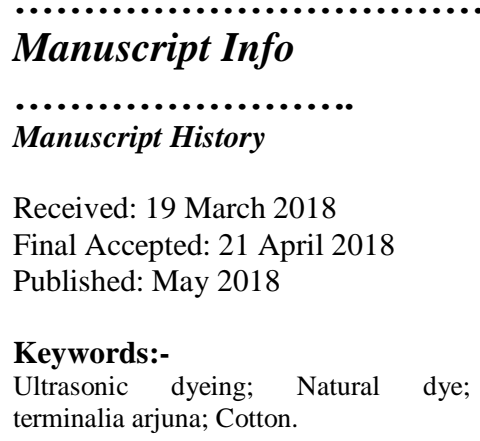

Ultrasonic dyeing; Natural dye;
terminalia arjuna; Cotton.

\begin{abstract}
Conventionally the dyeing of natural dyes from plant materials was done by boiling which requires longer time, higher temperature and metallic mordant to get good color fastness. Use of metallic mordants for dyeing posed some cruel effect to ecosystem. This study explained a suitable technique for more efficient natural dyeing using suitable mordant to improve the color fastness of natural dyes on cotton fabric. This study demonstrated ultrasonic cleaner as a technique of dyeing the colorant from a Terminalia arjuna was dyed at different ultrasonic volume and time. Results show the highest percentage of dye absorbed to cotton fabric using ultrasonic cleaner was produced at optimum condition of medium sonic volume in 80 minutes time. The utilization of ultrasonic cleaner was found to have significant improvement in the dyeing color of natural dyes to cotton fabric with lower dyeing temperature compared to traditional method.
\end{abstract}

Copy Right, IJAR, 2018,. All rights reserved.

\section{Introduction:-}

Textiles were dyed mainly by natural dyes up to the end of $19^{\text {th }}$ century. As a result of the stringent environmental standards laid down by many countries due to toxic and allergic reactions of artificial dyes, interest in use of natural dyes has increase rapidly [1]. All dyes were mainly obtained from plants and animals until about 150 years ago. Pigmentary molecules of natural dyes impart colour to the dyed materials people in the world have now a days become more conscious and aware of ecology and environmental cleanliness [2]. Hence, the revival of the use of natural dyes and their techniques are seen as an effective alternative to hazards of artificial dyes. There are some common draw backs of natural dyes. They are their non - reproducible and non-uniform lack of scientific information on the chemistry of dyeing and standardized dyeing methods [3].

Terminalia arjuna (T. arjuna) is 30 mater fall and 2-2.5 meter diameter free can the found in the south Asian region. It is an evergreen tree; its leaves are sprouting during February - April. In India it is associated as exoticism. If has medicinal quality: its barks acts as anti- dysenteric anti- pyretic, astringent, cardiotonic, lithotriptic , anticoagulant, hypolipidemi, antimicrobial [4] and antiuremic [5] agent. Phytoconstituents like triterperoids for cardiovascular properties, tannins and flavonoids for it anticancer, antimicrobial properties have been obtained from Terminalia arjuna [6]. Its bark powder is diuretic in cirrhosis of liver and relieves symptoms of hypertension [7]. The leaves of 
T.arjuna have analgesic and anti - inflammatory properties on mice . The study aims at finding out the preliminary photochemical screening of the Terminalia arjuna extract and to arrive at the antioxidant and antioricrobial activity. The present studying concerned with the extraction of natural dyes from the stem extracts of the barks of Terminalia arjuna and assess the dyeing ability by ultrasonication. As it grows easily and abundantly, and as the colorants can be easily extracted from it, Terminalia arjuna has become a rich source of natural dye.

\section{Materials and Methods:- \\ Materials:- \\ Source:-}

Terminalia arjuna barks were collected from Hoganekkal, Dharmapuri district, Tamil Nadu, India.

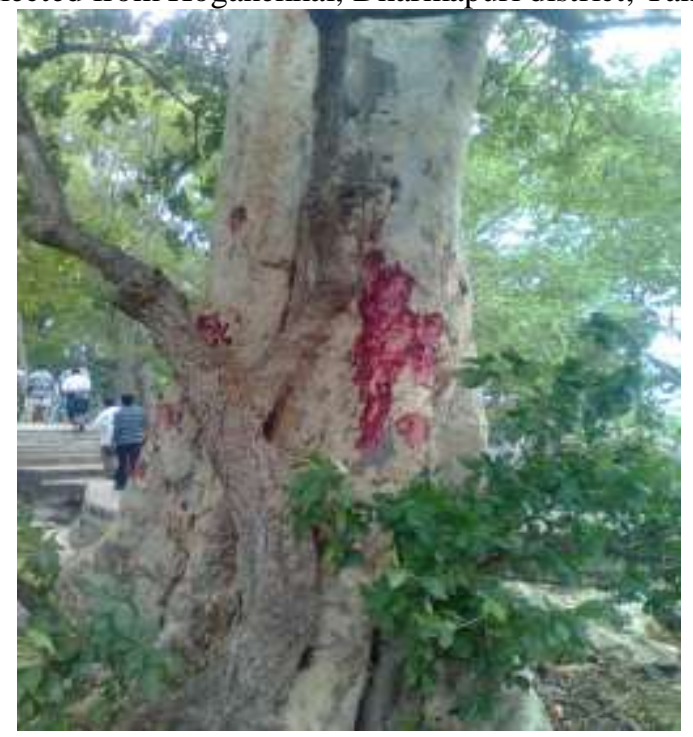

Figure 1:-Terminalia arjuna. $L$ tree

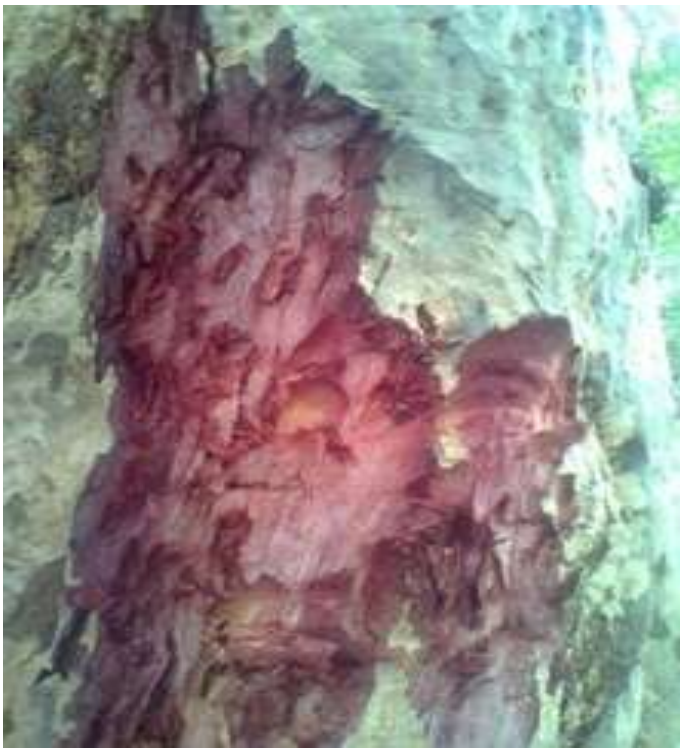

Figure 1:-Terminalia arjuna.L tree

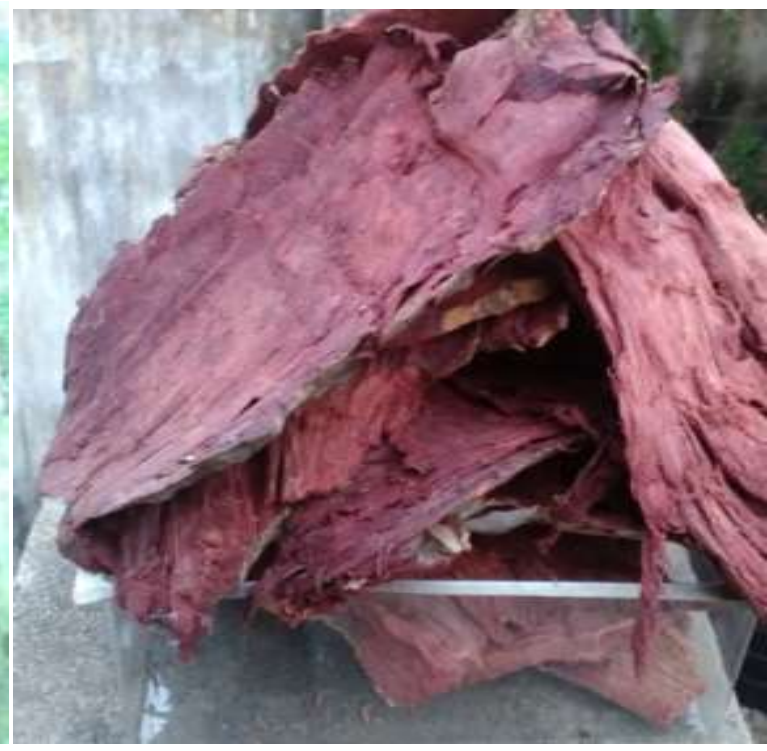

Figure 2:-Barks of Terminalia arjuna.L

\section{Substrate:-}

100\% cotton cloth was purchased from Saraswathi Departmental Stores, Kancheepuram. 


\section{Chemicals:-}

Laboratory grade chemicals-Alum, Stannous chloride, potassium dichromate, Nickel suphate, copper sulphate and ferrous sulphate were supplied by Maruthi trader Agencies, Kancheepuram. A natural mordant myrobolan, Turmeric, Cow dung, Banana sap juice was used for the study.

\section{Equipment used in the present work:-}

1. Weighing balance (Ciezen)

2. Codyson CD-4820 Ultrasonic Cleaner

\section{Methods:-}

\section{Extraction of Dyes:-}

Terminalia arjuna barks were cleaned by washing with water in order to remove dirt. The cleaned barks were dried under direct sunlight. Then the barks were ground into very small pieces in a grinder. A fine strainer was used to remove the wastages. Finally, the contents were weighted. After all these, process, 1 kilogram barks weighed, then, it is put in distilled water and heated in a breaker which in kept over a water bath for 2 hour. After this the contents were filtered and kept in a separate beaker.

\section{Effect of M: L Ratio:-}

The cotton samples were dyed with dye extracts keeping various M: L ratio as 1:10, 1:20, 1:30 and 1:40. It was observed that the dye uptake was good in M: L ratio 1:30.

\section{Dyeing of Fabrics:-}

The $100 \%$ bleached cotton fabrics were dyed with the dye extract keeping M: L Ratio at 1:30. Dyeing was carried out at $45^{\circ} \mathrm{C}$ and continued for 1 hour in ultrasonicator.

\section{Mordanting:-}

Different metallic salts and natural mordants were used to dye bleached cotton fabrics.

Pre-mordanting:-

Bleached cotton fabric was mordanted before dyeing using 3\% of any one of the chemical mordants like alum, stannous chloride, potassium dichromate, ferrous sulphate, nickel sulphate, copper sulphate and natural mordant like myrobolam, turmeric, cow dung and banana sap juice at $45^{\circ} \mathrm{c}$ for 1 hour with MLR of 1:30. The cotton fabric thus treated with metal salts were dyed using the dye extract.

\section{Post- mordanting:-}

Bleached cotton fabrics dyed with dye extract were made to become wet and put into different dye baths which contains the required amount of dye extract and water. Sodium sulphate was added to it after 20 minutes. The cotton fabric was dyed for about one hour at $45^{\circ} \mathrm{C}$. the fabrics thus dyed were removed, squeezed and put to treatment with metal salts without washing. Different metal salts were used for treatment using 3\% of any one of the chemical mordants like alum, stannous chloride, potassium dichromate, ferrous sulphate, nickel sulphate, copper sulphate and natural mordants such as myrobolan, turmeric, cow dung, Banana say juice at $45^{\circ} \mathrm{C}$ for 30 minutes with MLR of 1:30. The dyed fabrics were washed repeatedly in all the three methods in water and dried in air. At last, the dyed fabrics were put to soap with $2 \mathrm{gpl}$ soap solution at $50^{\circ} \mathrm{C}$ for 10 minutes. The fabrics were repeatedly washed in water and dried under sum.

\section{Simultaneous mordanting:-}

Here, the treatment of bleached cotton fabrics in carried out simultaneously using dye extract and metal salt using $3 \%$ of any one of the chemical mordants like alum, stannous chloride, potassium dichromate, ferrous sulphate, nickel sulphate, copper sulphate and natural mordants such as myrobolan, turmeric, cow dung, Banana say juice at $45^{\circ} \mathrm{C}$ for 1 hour with MLR 1:30.

\section{Dyeing in Ultrasonicator:-}

Ultrasound mainly generates cavitation in liquid medium and thus it enhances a wide variety of chemical and physical processes. To suitably induce cavitation, sonicator of $20 \mathrm{KHz}$ frequency is used (8). To facilitate better dye uptake, cavitation should cause formation and collapse of micro bubbles. For this sonicator is found to be very effective show in Figure 6. Initially the micro bubbles are unstable and gradually grow in the process of oscillation. At test, improve microbubbles implode violently and thus generate high pressures and temperature which are 
localized momentarily chemical reaction takes place between the fabric and the dye by this activated state as it results in forming shock waves and severe shear force which in capable of breaking chemical bonds.

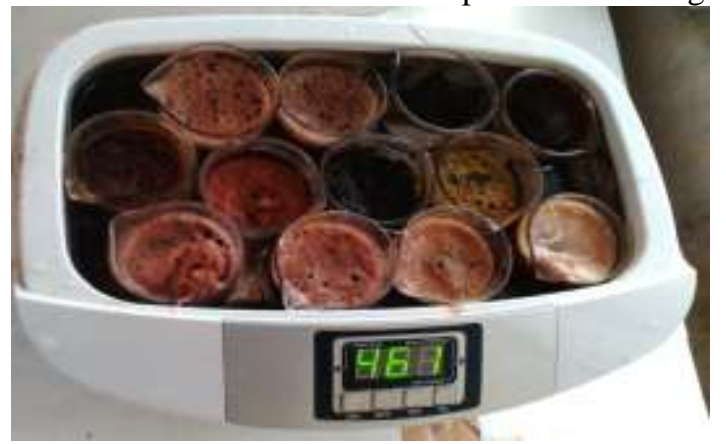

Figure 4:-Dyeing in Ultrasonicator

\section{Ultrasonic efficiency:-}

Ultrasonic efficiency $(\Delta K \%)$ in accelerating the dyeing rate was examined by introducing the following equation:

$$
(\Delta K \%)=100\left(\mathrm{~K}_{\mathrm{us}}-\mathrm{K}_{\mathrm{ch}}\right) / \mathrm{K}_{\mathrm{ch}}
$$

Where $\mathrm{K}_{\mathrm{us}}$ and $\mathrm{K}_{\mathrm{ch}}$ are the rate constants of dyeing with ultrasonic and conventional heating, respectively. The value of ultrasonic efficiency is positive for dyes indicating a favorable Effect of ultrasonic power on the dyeing process.

\section{Colour fastness:-}

The dyed samples were tested according to IS standards. Colour fastness to washing, light and rubbing, perspiration were determined from standard test methods IS-105-C03, IS-2454-85, IS-766-88 and IS-105-E04 respectively.

\section{Measurements of colour strength:-}

The K/S value of the undyed and dyed cotton fabrics was determined (9) by measuring surface reflectance of the samples using a computer-aided Macbeth 2020 plus reflectance spectrophotometer, using the following Kubelka Munk equation with the help of relevant software:

$$
K / S=(1-R)^{2} / 2 R
$$

Where $\mathrm{R}$ is the decimal fraction of the reflectance of the dyed samples at $\lambda . \mathrm{K}$ is the absorption coefficient and $\mathrm{S}$ is scattering coefficient (10)

\section{Results and Discussion:-}

Optimization aqueous extract of Terminalia arjuna:-

Aqueous Extract of Terminalia arjuna barks were found to discharge colour in hot water very easily. Increasing the quantity of barks $5 \mathrm{~g}$ to $20 \mathrm{~g}$ per $100 \mathrm{ml}$ water boiled for 1 hour is accompanied with the increase in colour strength and depth in colour [11]. It was observed that, colour of the dye extract was dark red colour as shown in Figure 5. 


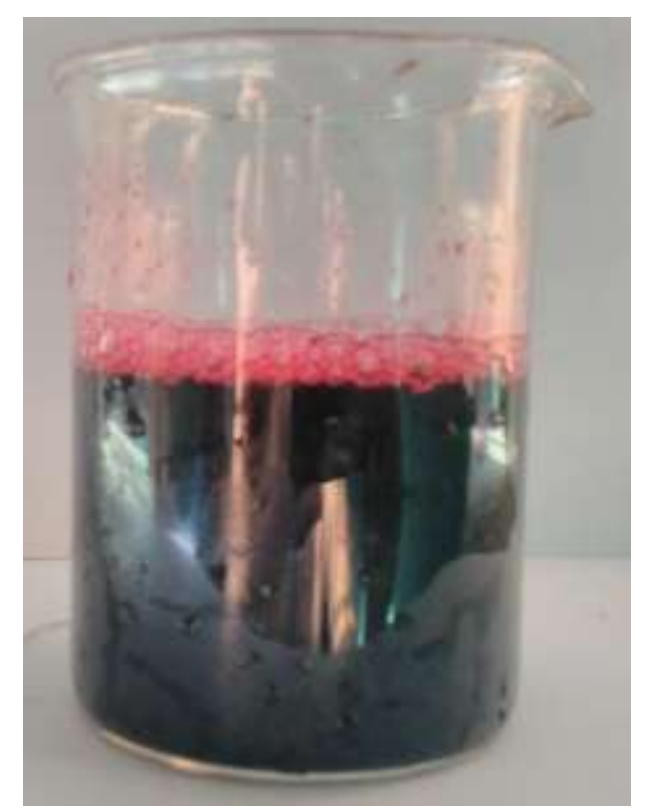

Figure 5:-Aqueous extract from the barks of Terminalia arjuna

\section{Dyeing behavior of the extract:-}

The colour strength values of cotton fabrics dyed with barks of Terminalia arjuna obtained in this study by using single mordanting method are presented in Tables 1. From the results, it was observed that Terminalia arjuna showed better colour strength values. In all the three dyeing methods, post mordantning method gave excellent results. In all the three methods of dyeing, the mordants ferrous sulphate and aluminium suphate show excellent colour strength values. For dyeing of cotton, $3 \%$ mordant concentration gave better results.

\section{Optimization of mordant with $\mathrm{K}$ / $\mathrm{S}$ values and colour Hues changes:-}

Various shades of colour were obtained from pre mordanted, simultaneous mordanted and post mordanted methods of dyeing. Different mordants determined the various shades of colour on the dyed fabric according to K/S values. As shown in Table 1. The different $\mathrm{L}^{*}, \mathrm{a}^{*}, \mathrm{~b}^{*}$ and $\mathrm{K} / \mathrm{S}$ values show in table 2 . The $\mathrm{L}^{*}$ values indicates perceived lightness or darkness where values of 0 indicates black and 100 indicates white. The values of $a^{*}$ and $b^{*}$ indicate red $(+a)$ and green (-a) while $b^{*}$ values indicate yellow (+a) and blue (-b). In pre-mordenting method $\mathrm{K} / \mathrm{S}$ values $\mathrm{FeSO}_{4}$ is $31.73, \mathrm{CuSO}_{4}$ is 28.51 , and the shades of colour in found to be darker. But when $\mathrm{L}^{*}$ values are lower, the hues of colour obtained will be danker. In post-mordanting method $\mathrm{K} / \mathrm{S}$ values for $\mathrm{FeSO}_{4}$ is $37.66, \mathrm{CuSO}_{4}$, in 32.5 and the shades of colour are found to be darker while the lower $\mathrm{L}^{*}$ values show lighter shades. In simultaneous mordanting method, $\mathrm{FeSO}_{4}$ is $18.63, \mathrm{CuSO}_{4}$ in 18.2 which shows the shades of colour are darker. But if the $\mathrm{L}^{*}$ values are lower, the shades of colour will be darker. The effect of mordtants on colour values of on cotton dyed with barks of Terminalia arjuna.L is shown in Figure 6. 


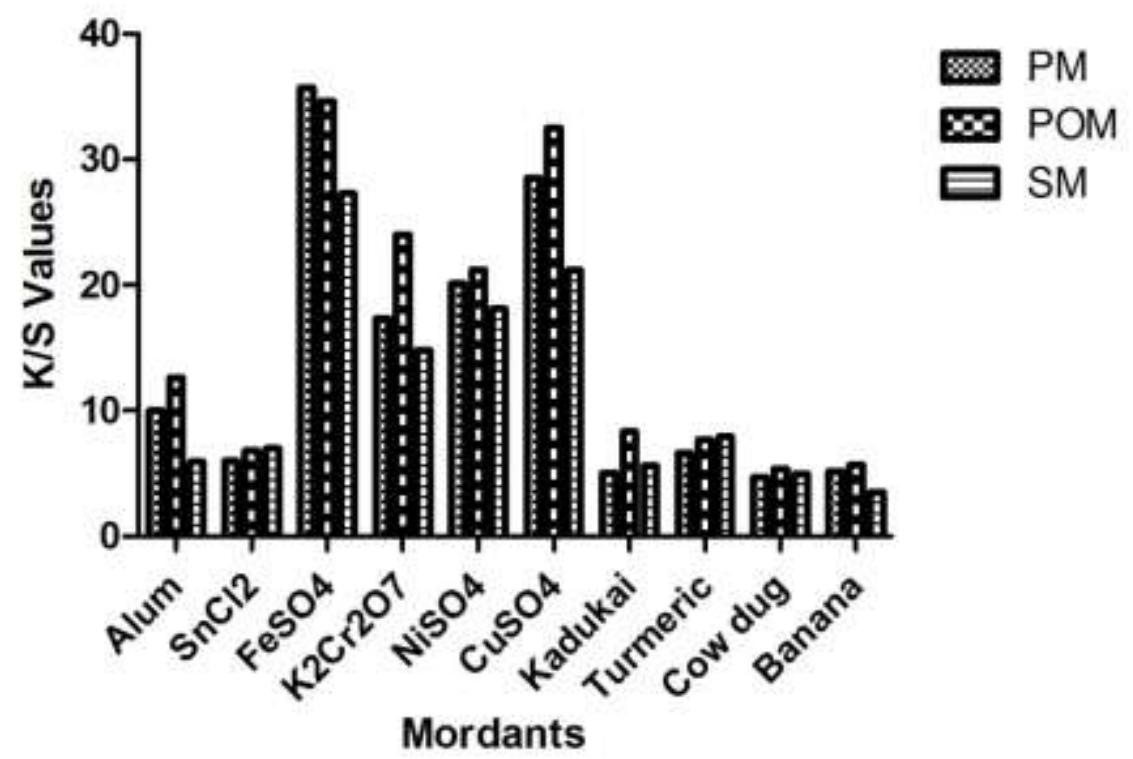

Figure 6:-Surface Colour Strength (Colour Strength (K/S Values) of Dyes Cotton Fabrics after Pre, Post and Simultaneous Mordanting Methods

\section{Colour fastness Properties:-}

The fastness properties of dyed cotton fabrics are shown in Table 3. It was observed that, dyeing with Terminalia arjuna. $L$ gave very good washing, light and rubbing, perspiration fastness properties. Overall, it could be used for commercial purposes and attain acceptable range 
Table 2:-Effect of dyed with barks extract of Terminalia arjuna (With or Without mordants) on the colour strength of cotton fabric

\begin{tabular}{|c|c|c|c|c|}
\hline $\begin{array}{l}\text { S. } \\
\text { No. }\end{array}$ & $\begin{array}{l}\text { Name of the } \\
\text { mordants }\end{array}$ & $\begin{array}{l}\text { Pre mordanting } \\
\text { (PM) }\end{array}$ & $\begin{array}{c}\text { Post } \\
\text { mordanting } \\
\text { (POM) }\end{array}$ & $\begin{array}{l}\text { Simulataneous } \\
\text { mordanting } \\
\text { (SM) }\end{array}$ \\
\hline 1 & Alum & & & \\
\hline 2 & $\mathrm{SnCl}_{2}$ & & & \\
\hline 3 & $\mathrm{FeSO}_{4}$ & & & \\
\hline 4 & $\mathrm{~K}_{2} \mathrm{Cr}_{2} \mathrm{O}_{7}$ & & & \\
\hline 5 & $\mathrm{NiSO}_{4}$ & & & \\
\hline 6 & $\mathrm{CuSO}_{4}$ & & & \\
\hline 7 & Myrobolan & & & \\
\hline 8 & Turmeric & & & \\
\hline 9 & Cow dung & & & \\
\hline 10 & Banana sap juice & & & \\
\hline
\end{tabular}




\begin{tabular}{|c|c|c|c|c|c|}
\hline Dyeing Method & \multicolumn{5}{|c|}{ Ultra sonicator } \\
\hline \multirow[t]{2}{*}{ Colour strength } & \multirow[t]{2}{*}{ Process } & \multirow[t]{2}{*}{$\mathrm{L}^{*}$} & \multirow[t]{2}{*}{$a^{*}$} & \multirow[t]{2}{*}{$b^{*}$} & K/S Value \\
\hline & & & & & $\mathrm{K} / \mathrm{S}(\lambda=420 \mathrm{~nm})$ \\
\hline \multirow[t]{3}{*}{ Without mordant } & Pre & 40.67 & 10.22 & 25.23 & 4.1 \\
\hline & Post & 48.45 & 12.22 & 15.21 & 3.38 \\
\hline & SM & 51.21 & 17.98 & 19.77 & 2.11 \\
\hline \multirow[t]{3}{*}{ Alum } & Pre & 49.37 & 12.97 & 18.98 & 10 \\
\hline & Post & 47.83 & 13.33 & 20.02 & 12.61 \\
\hline & SM & 72.32 & 12.25 & 8.32 & 3.98 \\
\hline \multirow[t]{3}{*}{$\mathrm{SnCl}_{2}$} & Pre & 61.06 & 12.23 & 18.11 & 5.99 \\
\hline & Post & 54.98 & 13.71 & 18.49 & 6.83 \\
\hline & SM & 72.15 & 11.21 & 10.25 & 3.17 \\
\hline \multirow[t]{3}{*}{$\mathrm{FeSO}_{4}$} & Pre & 30.9 & 3.23 & 7.75 & 31.73 \\
\hline & Post & 35.69 & 3.97 & 9.21 & 37.66 \\
\hline & SM & 54.17 & 6.25 & 1.85 & 18.63 \\
\hline \multirow[t]{3}{*}{$\mathrm{K}_{2} \mathrm{Cr}_{2} \mathrm{O}_{7}$} & Pre & 62.62 & 10.12 & 10.26 & 17.32 \\
\hline & Post & 48.95 & 12.18 & 17.66 & 24.02 \\
\hline & SM & 71.89 & 7.63 & 4.38 & 10.34 \\
\hline \multirow[t]{3}{*}{$\mathrm{NiSO}_{4}$} & Pre & 53.71 & 14.93 & 24.23 & 20.12 \\
\hline & Post & 48.22 & 14.97 & 23.92 & 21.2 \\
\hline & SM & 54.32 & 13.51 & 15.73 & 15.66 \\
\hline \multirow[t]{3}{*}{$\mathrm{CuSO}_{4}$} & Pre & 50.85 & 14.07 & 22.75 & 28.51 \\
\hline & Post & 42.56 & 15.14 & 23.43 & 32.5 \\
\hline & SM & 61.32 & 11.81 & 17.35 & 18.2 \\
\hline \multirow[t]{3}{*}{ Myrobolan } & Pre & 66.78 & 11.56 & 18.86 & 5.05 \\
\hline & Post & 57.27 & 14.94 & 25.07 & 8.31 \\
\hline & SM & 63.71 & 13.92 & 17.30 & 4.01 \\
\hline \multirow[t]{3}{*}{ Turmeric } & Pre & 60.19 & 12.89 & 33.08 & 6.63 \\
\hline & Post & 58.78 & 11.35 & 30.13 & 7.68 \\
\hline & SM & 64.81 & 13.81 & 24.99 & 3.63 \\
\hline \multirow[t]{3}{*}{ Cow dung } & Pre & 61.31 & 12.58 & 17.14 & 4.73 \\
\hline & Post & 52.45 & 15.22 & 20.21 & 5.38 \\
\hline & SM & 54.21 & 14.98 & 16.77 & 3.31 \\
\hline \multirow[t]{3}{*}{ Banana sap } & Pre & 65.12 & 13.48 & 18.48 & 5.19 \\
\hline & Post & 61.31 & 13.87 & 18.29 & 5.68 \\
\hline & SM & 58.8 & 14.98 & 13.62 & 3.75 \\
\hline
\end{tabular}




\begin{tabular}{|c|c|c|c|c|c|c|c|}
\hline Dyeing Method & \multicolumn{7}{|c|}{ Ultrasonicator } \\
\hline Fastness & \multirow[t]{2}{*}{ Process } & \multirow[t]{2}{*}{$\begin{array}{c}\text { Washing } \\
\text { fastness } \\
\text { (IS-105-C03) }\end{array}$} & \multirow[t]{2}{*}{$\begin{array}{l}\text { Light fastness } \\
\text { (IS-2454-85) }\end{array}$} & \multicolumn{2}{|c|}{$\begin{array}{c}\text { Rubbing } \\
\text { fastness } \\
\text { (IS-766-88) }\end{array}$} & \multicolumn{2}{|c|}{$\begin{array}{l}\text { Perspiration } \\
\text { (IS-105-E04) }\end{array}$} \\
\hline $\begin{array}{l}\text { Mordant concentration: } \\
3 \%\end{array}$ & & & & Dry & Wet & Acid & Alkali \\
\hline \multirow[t]{3}{*}{ Without mordant } & Pre & 3 & 3 & 3 & 3 & 3 & 3 \\
\hline & Post & 3 & 3 & 3 & 3 & 3 & 3 \\
\hline & SM & 3 & 3 & 3 & 3 & 3 & 3 \\
\hline \multirow[t]{3}{*}{ Alum } & Pre & 5 & 5 & 5 & 5 & 5 & 5 \\
\hline & Post & 5 & 5 & 5 & 5 & 5 & 5 \\
\hline & SM & 5 & 5 & 5 & 5 & 5 & 5 \\
\hline \multirow[t]{3}{*}{$\mathrm{SnCl}_{2}$} & Pre & 5 & $4-5$ & 5 & 5 & 5 & 5 \\
\hline & Post & 5 & $4-5$ & 5 & 5 & 5 & 5 \\
\hline & SM & 5 & $4-5$ & 5 & 5 & 5 & 5 \\
\hline \multirow[t]{3}{*}{$\mathrm{FeSO}_{4}$} & Pre & 5 & 5 & 5 & 5 & 5 & 5 \\
\hline & Post & 5 & 5 & 5 & 5 & 5 & 5 \\
\hline & SM & 5 & 5 & 5 & 5 & 5 & 5 \\
\hline \multirow[t]{3}{*}{$\mathrm{K}_{2} \mathrm{Cr}_{2} \mathrm{O}_{7}$} & Pre & 5 & $4-5$ & 5 & 5 & 5 & 5 \\
\hline & Post & 5 & $4-5$ & 5 & 5 & 5 & 5 \\
\hline & SM & 5 & $4-5$ & 5 & 5 & 5 & 5 \\
\hline \multirow[t]{3}{*}{$\mathrm{NiSO}_{4}$} & Pre & 5 & 5 & 5 & 5 & 5 & 5 \\
\hline & Post & 5 & 5 & 5 & 5 & 5 & 5 \\
\hline & SM & 5 & 5 & 5 & 5 & 5 & 5 \\
\hline \multirow[t]{3}{*}{$\mathrm{CuSO}_{4}$} & Pre & 5 & 5 & 5 & 5 & 5 & 5 \\
\hline & Post & 5 & 5 & 5 & 5 & 5 & 5 \\
\hline & $\mathrm{SM}$ & 5 & 5 & 5 & 5 & 5 & 5 \\
\hline \multirow[t]{3}{*}{ Myrobolan } & Pre & $3-4$ & $3-4$ & 4 & 4 & 4 & 4 \\
\hline & Post & 4 & 4 & 4 & 4 & 4 & 4 \\
\hline & SM & 4 & 4 & 4 & 4 & 4 & 4 \\
\hline \multirow[t]{3}{*}{ Turmeric } & Pre & $3-4$ & $3-4$ & 4 & 4 & 4 & 4 \\
\hline & Post & 4 & 4 & 4 & 4 & 4 & 4 \\
\hline & SM & 4 & 4 & 4 & 4 & 4 & 4 \\
\hline \multirow[t]{3}{*}{ Cow dung } & Pre & 3 & 3 & 3 & 3 & 3 & 3 \\
\hline & Post & 3 & $3-4$ & $3-4$ & $3-4$ & $3-4$ & $3-4$ \\
\hline & $\mathrm{SM}$ & 3 & $3-4$ & $3-4$ & $3-4$ & $3-4$ & $3-4$ \\
\hline \multirow[t]{3}{*}{ Banana sap } & Pre & $3-4$ & 4 & 4 & 3 & 4 & 4 \\
\hline & Post & $3-4$ & 4 & 4 & 3 & 4 & 4 \\
\hline & SM & 4 & 4 & 4 & $3-4$ & 4 & 4 \\
\hline
\end{tabular}

Table 3:-Fastness Properties for Cotton Fabric Dyed with Terminalia arjuna.L (with or Without mordant)

\section{Effect of ultrasound:-}

The process of ultrasound dyeing preferred because it ensures better dye uptakes even in lower temperature and lower chemical concentrations. It is for this reason that the textile industry is highly interested in ultrasound dyeing process. Though the results from laboratory scale studies are encouraging the ultrasound backed wet textile methods have not been implemented on an industrial scale as on date. Developing a specific ultrasonic energy device that could be adapted on to the jigger or winch for industrial application this in the main goal of this study. In general, acoustic cavitation in liquid media in th source of sonochemical activity. The acoustic cavitation that occurs near a solid surface generates microjets and these microjets will effectively facilitate the liquid to move with a higher velocity thus resulting in the diffusion of solute considerably inside the pores of the fabric. Improvement of diffusion may be the result of localized temperature rise and swelling effect due to ultrasound in the sonication process. The bubbles remaining in stable cavitation oscillate and it is responsible for the enhancement of molecular movement and stirring effect of the ultrasound. Particularly, in the case of cotton fabric dyeing, the effects of stable cavitation can be realized at the interface of the fabric and dye solution. Wet textile processes have improved due to 
the intense and accelerated mass transport, especially in intra your pores ouring to the undesired side - effects like the damage of fabric, mass transport intensification that uses a conventional approach like increasing temperatures in not always feasible. Our study of wing the ultrasound dyeing process showed that the exhaustion of dyes after on hour of dyeing in ultrasound method was $47 \%$ and $27.9 \%$ where as it was $88 \%$ and $82 \%$ by using the convention method. The process of dyeing the pretreated fabrics with natural dyes in a sonicator bath at a liquor ratio 1:30 commences with the temperature of the dye bath nothingness them $45^{\circ} \mathrm{c}$. the temperature is maintained at this level for 1 hour. The dye uptakes in the sonicator dyeing process showed considerable acceleration.

\section{Conclusions:-}

In conclusion, Terminalia arjuna, has been found to have good agronomic potential as a dye plant. Metal mordant when used in conjugation with ultrasonication for the extract Terminalia arjuna was found to enhance not only the dye uptake but also fastness properties of the cotton fabrics. Enhancement of dyeing ability was better than without mordant fabrics. Hence, ultrasonic method of fabric dyeing may be appropriate and beneficial for the society at large in future.

\section{Acknowledgement:-}

The authors express their sincere thanks to Professor Mr.M.Kandasamy, Professor, Department of English Thirumalai Engineering College, for his useful suggestions and help in the preparation of this manuscript.

\section{References:-}

1. Anitha,K., Prasad,S.N. (2007): Developing multiple natural dyes from flower parts of Gulmohur, Current Science, 92(12): 1681-1682.

2. SandeepBains, Singh, O.P., Ganganpreet Goraya and Manpreet Kang. (2003): Dyeing of Cotton with Golden drop dye, Journal of the Textile Association, 183-186.

3. Gulrajani, M .L.,GuptaDeepti. (1992): Natural Dye and their Application to Textiles Department of Textile Technology, IIT, Delhi), 25.

4. Mandal A, Das K, Nandi D K. In vitro bioactivity study of bark extract of Terminalia arjuna on probiotics, commercially available probiotic formulation. In J Phytopharmacol 2010; 1 (2): 109-113.

5. Das K, Chakraborty PP, Ghosh D, Nandi DK. Protective effect of aqueous extract of Terminalia arjuna against dehydrating induced oxidative stress and uremia in male rat. Iran J Pharma Res 2010; 9 (2): 153- 161.

6. Nema R, j ai n P, Khar e S, Pr adhan A, Gupt a A, Si ngh D. Antibacterial and antifungal activity of Terminalia arjuna leaves extract with special reference to flavanoids. Basic Res J Med Clin Sci 2012; 1(5): 6365 .

7. Chatterjee AS. The treatise on indian medicinal plants: Council of scientific and industrial research.New Delhi: Publication and Information Directorate; 1994.

8. Abramov OV. High intensity ultrasound: theory and industrial applications. London: Gordon andBreach;1998.

9. M.Kumaresan, P.N.Palnisamy and P.E.Kumar, 2011, Application of Ecofriendly Natural Dye Obtainedfrom flower of Spathodea Campanulata on Silk, European Journal of Scientific Research, Vol.52, No.3,pp.306-312.

10. S. Habibzadeh, H. Tayebi, E..Ekrami, A.Shams Nateri M.Allahnia and M.Bahmani, 2010, Silk Dyeing Using Saw-Wood of the Zelkoa Forest Tree, World Applied Journal, 9(3), 295-299.

11. Rakhi Shanker and Padma S Vangar, 2006, dyeing cotton, wool, and silk with Hibiscus mutabilies(Gulzuba), Dyes and Pigments, Elsevier, pp-1-6. 